\title{
HISTÓRIA E FILOSOFIA DA EDUCAÇÃO: DA PAIDEIA GREGA AO PRAGMATISMO ROMANO
}

\begin{abstract}
Antônio Roberto Xavier ${ }^{1}$
Resumo: Este artigo tem como escopo principal compreender e atualizar um debate histórico-filosófico sobre educação e seus aspectos epistemológicos, traçando, sucintamente, uma ponte cognitiva entre a Paideia grega e o pragmatismo educacional romano. Este artigo é uma revisão bibliográfica de abordagem qualitativa e segue o método dedutivo interpretacional dos conteúdos presentes em fontes secundárias. Ao desenvolver está escrita, partiu-se do pressuposto de que educação é um daqueles termos de significados bem amplos, que, por mais que se procure definir, não se conseguem esgotar as acepções e concepções acerca de seus significados e implicações em âmbito coletivo nos diferentes momentos do saber-fazer humano. Todavia, em razão de seu variado e volumoso arcabouço de sentidos e por ser sua busca uma constante das e nas sociedades, o uso ou mau uso do vocábulo educação, muitas vezes, tem se tornado banal ou irreflexivo, praxiologicamente. O uso do vocábulo educação, em certas circunstâncias, tem deixado de representar suas reais finalidades por ser empregado de forma deslocada dos padrões sociais, morais e/ou éticos pertinentes. Com efeito, é possível que, ao se falar sobre educação, venham à tona, através do senso comum, aspectos referentes às escolas, seus muros, grades, portões, cadeados, direção, coordenação, professores, quadros e uma infindável lista de diretrizes, normas e sanções raramente cumpridas. Entretanto, conforme é demonstrado neste trabalho, educação é uma prática social indispensável para o viver e evoluir positivamente em sociedade. Para tanto, necessário se faz entender os diversos princípios, funções e demandas educacionais nos diferentes contextos da história da humanidade.
\end{abstract}

Palavras-chave: Educação. História. Filosofia. Paideia Grega. Pragmatismo Romano.

Abstract: This article has the scope to understand and update a historical-philosophical debate about education and its epistemological aspects tracing briefly a cognitive bridge between the Greek Paideia and the Roman educational pragmatism. This article is a literature review, qualitative approach and follows the interpretational deductive method of the contents on secondary sources. In developing this writing, he broke than

\footnotetext{
1 Pós-Doutorando pela Universidade Federal da Paraíba (UFPB), doutor em Educação pela Universidade Federal do Ceará (UFC), mestre em Políticas Públicas e Sociedade e em Planejamento em Políticas Públicas, ambas as formações pela Universidade Estadual do Ceará (UECE), especialista em História e Sociologia pela Universidade Regional do Cariri (URCA) e graduado em História pela UECE e em Pedagogia pela Faculdade Kurios (FAK). Membro titular do Conselho Superior Universitário (Consuni). Professor adjunto da Universidade da Integração Internacional da Lusofonia Afro-Brasileira (Unilab), lotado no Instituto de Ciências Sociais Aplicadas (ICSA). Professor permanente do Mestrado Acadêmico em Sociobiodiversidade e Tecnologias Sustentáveis (MASTS) da Unilab. Atua nas seguintes Linhas de Pesquisa: 1) Políticas Públicas, Governo e Sociedade; 2) Políticas Sociais; 3) História e Memória da Educação; 4) Etnociências, Saberes Populares e Interdisciplinaridade. Desenvolve também pesquisas em Bio(auto)grafia de professores quilombolas e professores leigos, além de Gênero, Museologia, Patrimônio; Oralidade, Memória e Narrativas Biográficas. É líder do Grupo de Pesquisa Gestão de Políticas Sociais (GPS), vice-líder do Grupo de Pesquisa História, Cultura, Memória e Educação (Hicume), ambos da Unilab, vinculados ao Conselho Nacional de Desenvolvimento Científico e Tecnológico (CNPq), e integrante do Núcleo de História e Memória da Educação (Nhime) da UFC, também vinculado ao CNPq. E-mail: <historiadoroberto@hotmail.com>. Lattes: <http://lattes.cnpq.br/6041487079855448>.
} 
education assumption is one of those terms of very broad meaning that for longer look set you can not exhaust the meanings and conceptions about their meanings and implications in a community basis at different times of know- make human. However, because of their varied and voluminous framework of meanings and to be your search of a constant and societies, the use or misuse of the word education, often has become banal or unreflective, praxiologicamente. The use of the word education in certain circumstances, has failed to represent their real purposes for being employee so displaced social standards. Moral and / or ethical relevant. Indeed, it is possible to talk about education come to the fore, through common sense, this refers to schools, its walls, railings, gates, padlocks, direction, coordination, teachers, staff and an endless list of guidelines, norms and sanctions rarely met. However, as demonstrated in this work, education is an indispensable social practice to live and evolve positively in society. Therefore, the need to make understand several principles, functions and educational demands in different areas of human history.

Keywords: Education. History. Philosophy. Paideia Greek. Pragmatism Romano.

Etimologicamente, a palavra “educação", em língua portuguesa, tem suas origens vinculadas à palavra grega notiSeía, à latina educatio, à inglesa education, à francesa éducation, à alemã erziehung, tendo seus vocábulos correspondentes nas demais línguas relacionados sempre ao sentido genérico, primeiramente, de transmissão e aprendizagem do conjunto das técnicas de trabalho (cultivo), visando à sobrevivência humana e ao respeito à moral e à religiosidade. Num segundo momento, o vocábulo educação é a arte compreensiva do legado cultural (das boas artes, da poesia, da filosofia) de geração para geração, com vistas ao aperfeiçoamento das técnicas anteriores, da moral e do seguimento dos padrões sociais estabelecidos para formar o homem singular na sua forma genuína. Essa circunstância aplica-se desde as sociedades primitivas.

1 - O primeiro conceito de E. como se disse, é posto em prática pelas sociedades primitivas e também, parcialmente, nas sociedades secundárias, sobretudo no que tange à E. moral e religiosa. Consiste na transmissão pura e simples das técnicas consideradas válidas e na transmissão simultânea da crença no caráter sagrado, portanto imutável, de tais técnicas. Na tradição pedagógica do Ocidente, esse conceito de E., por motivos óbvios, foi formulado e defendido poucas vezes. [...]. 2 - No segundo conceito de E., a transmissão das técnicas já adquiridas tem sobretudo a finalidade de possibilitar o aperfeiçoamento dessas técnicas através da iniciativa dos indivíduos. Nesse aspecto, a E. é definida não do ponto de vista da sociedade, mas do ponto de vista do indivíduo: a formação do indivíduo, sua 
cultura, torna-se o fim da educação. A definição de E. na tradição pedagógica do Ocidente obedece inteiramente a essa exigência. [...]. Esses conceitos repetem-se com tal uniformidade na tradição pedagógica que não chegam a constituir novidade do ponto de vista filosófico. (Abbagnano, 1998, p. 306-307).

Pelo visto, a educação surge pari passu à existência humana, e a primeira forma de educação se dá de maneira informal e tem por finalidade a sobrevivência da própria espécie humana. No decorrer de seu desenvolvimento, há o domínio e o aperfeiçoamento das técnicas educativas transformadoras do habitat natural. As características dessa educação concentram-se na transmissão e perpetuação do legado cultural nas mais diversas e distintas coletividades humanas. Inicialmente, a transmissão e o aprendizado do/no meio em que os seres vivos surgiram ocorreram por meio dos gestos e depois por meio da oralidade, visando à sobrevivência da espécie. "Numa vasta aceitação, a educação designa o conjunto das influências do ambiente, as dos homens ou as das coisas, chegando a transformar o comportamento do indivíduo que as experimenta [...], educação da vida" (Arenilla et al., 2001, p. 167).

Segundo Bergson (1941), a educação tem como função precípua levar o ser humano a ousar na sua ação, a criar através dessa ação, necessitando esse ser humano de liberdade, podendo a educação fomentar a liberdade para que o ser se energize em atos com todo seu espírito. Essa função, se, por um lado, é coerente com o pensamento foucaultiano (2011); por outro, não condiz com a reprodução conservadora da moral social atribuída ao papel da educação burguesa, sobretudo dos defensores positivistas/funcionalistas (Freire, 1976; Marx et al., 1976; Meksenas, 1988).

Em linhas gerais, parece ser válido afirmar que a educação é um processo tanto de ensino-aprendizagem quanto de socialização/endoculturação em espaços e contextos sociais no âmbito do desenvolvimento humano. Contudo, a educação, sobretudo a formal, não se processa por si só. Seu desenvolvimento depende de profissionais na área, que, dependendo de suas desenvolturas, tal educação galgará êxito ou não, sobretudo para a inserção e atuação no mundo do trabalho. É sobre esses profissionais e a melhoria da educação que Ribeiro (2011, p. 472-475) direciona sua atenção, afirmando e reafirmando que:

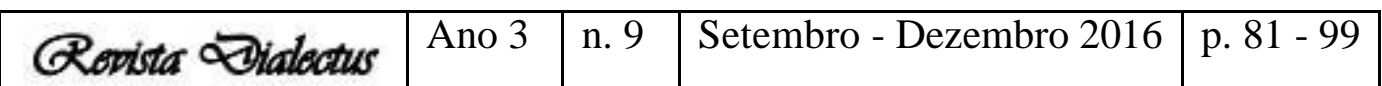


Para a melhoria da educação básica, a formação dos educadores deve estar em consonância com os resultados pretendidos, permitindo que esses profissionais da educação se beneficiem simultaneamente dos programas de capacitação em serviço e outros incentivos relacionados à obtenção desses resultados [...]. Todos agora são chamados a participar nesse processo de reforma da educação, sem distinção de cor, raça, credo, gênero ou classe social [...]. A estratégia adotada pelo capital, além de valorizar a capacidade tecnológica, é estimular o aumento da competência, da eficácia e da produtividade da força de trabalho e do controle social recomendando, para tal, o investimento na educação básica na população dos países periféricos e emergentes. Cabendo ao professor ser o guardião dos interesses inerentes ao próprio processo de reprodução ampliada do sistema, como bem expressa o modelo do aprender a aprender adotado pela ONU, pela Unesco e pelo Banco Mundial, posicionados aqui como legítimos representantes da sociedade de mercado.

A moldura pensante à qual a educação pode ser vinculada é, sem dúvida, o grande desafio atual. Essa é mais uma reflexão que envolve a educação formal de nossos tempos. Porém, não sendo estanque somente nesses aspectos, a educação também não se resume apenas ao tipo formal, podendo também ser informal e não formal, dependendo do ambiente e do grupo social nos quais ela se insere. A educação formal está relacionada com o sistema escolar institucionalizado, com legislação própria, estruturado, gradual, hierarquizado, disciplinado e disciplinador, com programas, planejamento, conteúdos sistematizados, currículo e público-alvo previamente selecionados e delimitados. Esse modelo de educação é padronizado pelo poder público ou privado e, via de regra, tem que cumprir as determinações estabelecidas no âmbito das instituições de ensino, visando alcançar, como finalidade, a formação de indivíduo ativo, perceptivo, criativo, habilidoso, competente e, acima de tudo, capaz de atender às demandas do mercado de trabalho, compatível com a tríade economia-tecnologia-telecomunicação em constante transformação em tempo real.

Nesse tipo de educação, o educador é facilmente identificado como sendo o(a) professor(a) que precisa ser especializado(a) por área de ensino e viver numa progressiva dinâmica de aperfeiçoamento diante das transformações e exigências do mundo do trabalho e das tramas da política e da politicagem. "Na educação formal espera-se, sobretudo que haja uma aprendizagem efetiva (que, infelizmente nem sempre

\begin{tabular}{|l|l|l|l|l|}
\hline Qevista Dialactus & Ano 3 & n. 9 & Setembro - Dezembro 2016 & p. 81 - 99 \\
\hline
\end{tabular}


ocorre), além da certificação e titulação que capacitam os indivíduos a seguir para graus mais avançados" (Gohn, 2006, p. 30). Além do mais:

A educação formal tem objetivos claros e específicos e é representada principalmente pelas escolas e universidades. Ela depende de uma diretriz educacional centralizada como currículo, com estruturas hierárquicas e burocráticas, determinadas em nível nacional, com órgãos fiscalizadores dos ministérios da educação. A educação não-formal é mais difusa, menos hierárquica e menos burocrática. Os programas da educação não-formal não precisam necessariamente seguir um sistema seqüencial e hierárquico de 'progressão'. Podem ter duração variável, e podem, ou não, conceder certificados de aprendizagem. (Gadotti, 2005, p. 2).

No tocante à educação não formal, muitas vezes confundida com a educação informal, o(a) educador(a) ou educadores(as) emerge(m) do processo integrado que ocorre internamente em um grupo e em comum acordo os integrantes escolhem intencionalmente os espaços não institucionalizados para as práticas educativas e sociointerativas. Nessa forma de educação, as diretrizes educacionais são definidas conjuntamente pelos integrantes da coletividade e a participação dos indivíduos é optativa ou condicionada por forças circunstanciais. O processo educativo não formal vai além das prerrogativas escolares, levando em conta a história de vida e suas realidades individuais.

A educação não formal capacita os indivíduos a se tornarem cidadãos do mundo, no mundo. Sua finalidade que circunda é abrir janelas de conhecimento sobre o mundo que circunda os indivíduos e suas relações sociais. Seus objetivos não são dados a priori, eles se constroem no processo interativo, gerando um processo educativo. Um modo de educar surge como resultado do processo voltado para os interesses e as necessidades que dele participa. A construção de relações sociais baseadas em princípios de igualdade e justiça social, quando presentes num dado grupo social, fortalece o exercício da cidadania. A transmissão de informação e formação política e sociocultural é uma meta na educação não formal. Ela prepara os cidadãos, educa o ser humano para a civilidade, em oposição à barbárie, ao egoísmo, individualismo, etc. (Gohn, 2006, p. 29-30).

A educação não formal busca a formação de um ser consciente e de mentalidade crítica emancipada de certas alienações impostas por outros seres, grupos 
ou instituições. Nesse tipo de educação, busca-se uma aprendizagem teórico-prática conscientemente.

Com relação à educação informal, vincula-se diretamente à transmissão do legado cultural de geração para geração através da experiência sentida e vivida, configurando-se, assim, como objeto de abordagem universal com ou sem os códigos escritos e se desenvolve de indivíduo para indivíduo, grupo ou coletividade sem nenhum rigor oficializado. A educação informal é "[...] aquela que os indivíduos aprendem durante seu processo de socialização - na família, bairro, clube, amigos etc., carregada de valores e culturas próprias, de pertencimento e sentimentos herdados" (Gohn, 2006, p. 28).

Desse modo, a educação apresenta-se como um imenso palco de oportunidades para o indivíduo se libertar e caminhar por suas próprias aspirações e inspirações. Nesse sentido, a educação é detentora de um leque de funções e abre uma variedade infindável de possibilidades para o homem e suas realizações. Mas, para chegar a essas condições gerais e parciais da atualidade no mundo ocidental, a educação vem atravessando uma longa trajetória heterogênea nos diferentes contextos históricos.

\section{Educação ocidental: o legado da Paideia ${ }^{2}$}

O percurso evolutivo da educação, tomando por base o lado ocidental e a Grécia, herdeira das culturas de outros impérios, como as dos impérios egípcio e pérsico, prosseguiu galgando sempre inovações, renovações e aperfeiçoamento. Aliás, diga-se de passagem, foi do Egito, apesar da existência de outros povos e impérios mais antigos, que a Grécia recebeu as mais fecundas influências em se tratando de educação e instrução nos diversos e variados aspectos.

Do Egito é que nos chegaram os testemunhos mais antigos e talvez mais ricos sobre todos os aspectos da civilização e, em particular, sobre a educação. Embora a pesquisa arqueológica a cada ano venha descobrindo provas de outras civilizações até mais antigas, ainda assim, para os povos que reconhecem sua origem histórica na antiguidade clássica greco-romana e nas posteriores manifestações cristãs que introduziram nela muitos

\footnotetext{
2 No sentido de cultura para os gregos.
} 
elementos do Oriente Próximo, o Egito está no início da sua história. (Manacorda, 2006, p. 9).

O reconhecimento da supremacia instrucional egípcia foi reconhecido pelos fenícios, mesopotâmicos, gregos (como Platão) e tantos outros povos antigos e modernos. De fato, o que se tornou ciências, como a geometria, a matemática em geral, astronomia, teologia, medicina, arquitetura, dentre tantas outras formas de ensinamentos práticos e teóricos que datam da "[...] $3^{\text {a }}$ dinastia (século XXVII a.C.)", foi legado do Império egípcio (Manacorda, 2006, p. 11).

O aperfeiçoamento, a assimilação e a praticidade das técnicas de captação cultural antes e pós-escrita são bem anteriores ao mundo grego e seus conquistados. Entretanto, é dessas terras gregas que o legado cultural/educacional do Ocidente encontrará suas bases e fundamentações. Por isso, algumas peculiaridades merecem ser mencionadas com relação ao desenvolvimento educativo a partir do legado que os gregos assimilaram de outros povos e repassaram para os demais. Entre tantas especificidades pertinentes ao legado educacional do Oriente e do Ocidente, talvez a que mais resuma de maneira rápida seja a do primado da conservação, transmissão e reprodução das tradições culturais coletivas na parte oriental e a da valoração do desenvolvimento filosófico, liberal e individual na parte ocidental, pelo menos para $10 \%$ dos habitantes gregos, já que cerca de $90 \%$ deles eram escravos, sem terem direito à educação (Piletti et al., 2007).

A formação do povo grego compreende os seguintes períodos: Período Pré-Homérico (2500-1100 a.C.) ou heroico, em que aconteceu a formação do povo grego com a junção de várias tribos. Nesse período, prevalece a crença mitológica. Período Homérico (900-750 a.C.), fase retratada pelos poemas de Homero, Ilíada e Odisseia. Nesse período, a prática da oralidade foi bastante utilizada para a transmissão do legado cultural na Grécia. Continua a concepção mítica de mundo na qual as explicações para a vida e os acontecimentos são e devem ser guiadas e decididas pelo sobrenatural. São responsáveis pela reprodução e transmissão oral desses mitos e tradições os cantadores ambulantes, aedos e rapsodos predominantemente. "A educação nesse período [...] compreende um duplo ideal de homem, ou seja, o homem de ação e o homem de sabedoria. Esse duplo ideal - sabedoria e poder de ação - tinha que ser atingido por todos os gregos livres" (Piletti et al., 2007, p. 59). 


\section{HISTÓRIA E FILOSOFIA DA EDUCACÃO: DA PAIDEIA GREGA...}

Antônio Roberto Xavier

Período Arcaico (século VII e VI a.C.), fase da formação das CidadesEstados e da presença da escrita, da moeda, da lei, dos sofistas e da vida urbana na pólis grega, com instrução voltada exclusivamente para a preparação física militar visando à guerra na Cidade-Estado de Esparta. Não há ainda uma atenção voltada para a educação do homem em geral e para a compreensão humanística de mundo. Plutarco explica qual era o tipo de educação em Esparta nesse período: "Em relação à instrução, eles recebiam apenas exatamente o que era absolutamente necessário. Todo o restante de sua educação tinha em vista torná-los sujeitos ao comando, suportar os trabalhos, lutar e conquistar" (Piletti et al., 2007, p. 60).

Com efeito, em Esparta, nesse contexto, as crianças, ao nascerem doentes ou com alguma deficiência, eram jogadas de um despenhadeiro ou adotadas por um hilota. Caso fossem sadias e do sexo masculino, ao completarem 7 anos de idade, eram entregues ao Estado para serem treinadas nos estabelecimentos militares. As meninas ficavam com as mães para aprenderem as atividades domésticas. Os meninos, ao completarem 12 anos, dedicavam-se às práticas esportivas e, ao completarem a maioridade, recebiam treinamentos rigorosos de preparação para a guerra: “[...] tinham de andar descalços e nus para ficarem com a pele mais grossa e eram chicoteados até sangrar para aprenderem a dominar a dor. Dos 20 aos 30 anos permaneciam nos quartéis à espera de convocação para alguma guerra" (Azevedo et al., 2005, p. 58). Ao completarem 30 anos, os homens conquistavam a cidadania (liberdade civil), porém só estavam liberados do serviço militar após completarem 60 anos de idade. Essa era a forma de educação espartana.

Por outro lado, na Cidade-Estado de Atenas, sobretudo a partir do final do século VI e século V a.C., a permeabilidade filosófica e científica encontram espaços propícios. A educação intelectual é colocada no mesmo patamar da educação física. $\mathrm{O}$ objetivo era formar o homem em sua plenitude tanto corpórea quanto intelectual. E a formação corpórea estava vinculada à arte e à estética. O Estado não mais é visto apenas como máquina de conquista, mas a serviço de assegurar a liberdade do cidadão ateniense. Com efeito, ao invés de ser entregue aos cuidados do Estado para servir à guerra como em Esparta, em Atenas, a criança aos 7 anos de idade era entregue aos cuidados de um pedagogo. "Os pedagogos eram escravos ou servos encarregados" de levar e trazer as crianças às escolas. "O menino ateniense freqüentava dois tipos

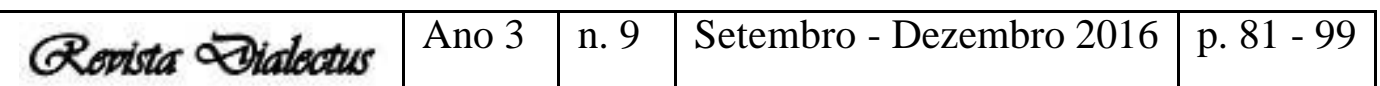


diferentes de escolas: a escola de música e a escola de ginástica ou palestra" (Piletti et al., 2007, p. 61-62).

Mas a busca de uma educação de um duplo ideal de homem - de ação e de sabedoria - persistia. Essa meta vai ser possível no século V a.C., no chamado século de Péricles, por suas conquistas e apogeu ateniense. É no anseio dessa busca que surgem os sofistas (450-400 a.C.). Nesse período, Atenas enfrentava guerras contra os persas. Passados os combates e em plena vigência das leis constitucionais de Clístenes, que priorizava a liberdade política, a educação tinha por cerne reivindicar a liberdade individual e o crescimento intelectual de cada cidadão ateniense. Mas havia um obstáculo: quem estaria preparado para a nova missão educacional com essa dupla finalidade? É a partir dessa necessidade que surgem os novos professores: os sofistas ou os sábios. Essa era a nova categoria de docentes que a sociedade ateniense exigia, pois os sofistas eram considerados mestres de retórica e cultura a tal ponto de terem influenciado o universo intelectual grego nos séculos V e IV a.C. Nesse sentido, mesmo sem ser considerada como uma Escola, os sofistas ensinavam:

$1^{\circ} \mathrm{O}$ interesse filosófico concentra-se no homem e em seus problemas, o que os sofistas tiveram em comum com Sócrates. $2^{\circ} \mathrm{O}$ conhecimento reduz-se à opinião e o bem, à utilidade. Consequientemente, reconhece-se da relatividade da verdade e dos valores morais, que mudariam segundo o lugar e o tempo. $3^{\circ}$ Erística: habilidade em refutar e sustentar ao mesmo tempo teses contraditórias. $4^{\circ}$ Oposição entre natureza e lei; na natureza, prevalece o direito do mais forte. Nem todos os sofistas defendem essas teses: os grandes sofistas da época de Sócrates (Protágoras e Górgias) sustentaram principalmente as duas primeiras. As outras foram apanágio da segunda geração de sofistas. (Abbagnano, 1998, p. 918).

O ensinamento dos sofistas, principalmente efetivado em praças públicas, não foi suficientemente capaz de se consolidar como a educação pretendida pela sociedade grega. Era um tipo de educação fragmentada, de certos tópicos de retórica, dialética ou história, que se concentrava em pontos cruciais para serem defendidos ou expostos em momentos exclusivos. Ainda por cima, os sofistas exigiam pagamento de seus ensinamentos, elencavam a valorização individual, desprezavam a existência de ideias universais, não mantinham uma relação de integração com seus discentes e para

\begin{tabular}{|c|c|c|c|}
\hline QRovita Dialectus & Ano 3 & n. 9 & Setembro - Dezembro 2016 \\
\hline
\end{tabular}


eles a moralidade devia se fundamentar na razão e não nos costumes e tradições apregoadas em períodos anteriores (Piletti et al., 2007).

A propósito, a questão de se estabelecer um planejamento educacional exequível e satisfatório às apreensões da sociedade grega continuava como barreira a ser superada. Foi aí que surgiu a figura de Sócrates (470-399 a.C.), que, tomando como base a máxima do sofista Protágoras, quem postulava que "o homem é a medida de todas as coisas", que parte do princípio de que, para se atingir o ápice intelectual, o homem necessita, em primeiro lugar, conhecer a si mesmo. É a partir da formação da consciência individual que o homem deveria procurar compreender a finalidade da vida e da educação. Assim, a educação não deveria se basear em informações superficiais ou fragmentadas para ser usada em certas ocasiões, mas deveria despertar na mente do ser sua capacidade de procurar compreender as coisas a partir da experiência individual de cada um. É a partir do fazer nascer as ideias da própria consciência do indivíduo que se alcança o conhecimento real. Essa era a tônica da maiêutica socrática: o nascimento (parto) das ideias. Nesse sentido, é a partir do final do século V a.C. que a educação grega transbordará suas influências, principalmente para o lado do mundo ocidental, e segue adiante.

O Período Clássico (final do século V a.C. ao século IV d.C.), fase correspondente ao apogeu e decadência da civilização grega e à ascensão e decadência da civilização romana ocidental com o desenvolvimento das leis e políticas públicas para a sociedade. A educação clássica se desenvolve voltada para a razão humana. $\mathrm{O}$ cosmocentrismo é priorizado em todas as suas formas. Ao contrário dos povos orientais, que atribuíam a educação e a autoridade máxima às divindades, na Grécia Clássica o homem era livre para pensar, criticar, refletir e descobrir a partir dele mesmo a racionalidade da vida. O homem seria a medida dele próprio, sendo capaz de transformar, entender e usar em seu próprio benefício os recursos da natureza. Surgem os grandes educadores, os filósofos Sócrates, Platão (também chamado de o primeiro pedagogo) e Aristóteles (discípulo de Platão). A esses dois últimos são atribuídas as duas principais tendências do conhecimento filosófico que perduram até nossos dias: a tendência idealista platônica e a realista aristotélica.

A educação clássica é tomada a cabo visando à formação humanística, enquanto a instrução utilitarista do período anterior centrava-se na educação física para

\begin{tabular}{|c|c|c|c|}
\hline Qovista Dialectus & Ano 3 & n. 9 & Setembro - Dezembro 2016 \\
\hline
\end{tabular}


o desenvolvimento corpóreo e na arte da guerra; a continuação da educação clássica, sobretudo em Atenas, concentra-se na formação filosófica, nas letras, na arte, na educação física moral e estética, na música, na retórica, etc. O currículo escolar em Atenas era composto por três partes básicas: letras, música e ginástica com docentes especializados.

A elaboração da educação clássica transforma progressivamente a formação aristocrática. Acompanha a vulgarização da escrita alfabética e o aparecimento, devido à extensão das relações comerciais no Mediterrâneo, de novas classes sociais. Ao desporto e à música acrescentam-se os ensinos - leitura, escrita, retórica, filosofia - exigidos pelas novas necessidades. De simples técnica de conservação comunitária, a educação torna-se objetivo em si. O ensino da música (aprendizagem coral e instrumental) e da ginástica, sob autoridade do pédotribe que realiza a preparação para as competições atléticas do jogos panhelênicos, procura sempre a formação dos caracteres e dos cidadãos. Daí a importância pedagógica e cultural dos três locais de educação do corpo, o ginásio, a palestra, o estádio. $\mathrm{O}$ gramático ensina a leitura, a escrita e o cálculo. Ensino sumário, extenso, porém, a vários anos, quatro segundo Platão, devido à dificuldade dos textos sem pontuação e onde as palavras não são separadas, apela a uma disciplina rigorosa, à mecanização salmodiavam-se as palavras, as sílabas, as composições de sílabas - e sobretudo à memória: recitação dos textos memorizados. (Arenilla et al., 2001, p. 179-180).

Com o passar do tempo, a figura do pédotribe $e^{3}$ é gradativamente substituída pela figura do pedagogo (escravo que levava os filhos dos senhores para as escolas e lhes ensinava outras atividades da vida e sobre a vida). $\mathrm{O}$ termo pedagogo, derivado de pedagogia, será utilizado como referência ao profissional especializado em educação. Nesse sentido, a pedagogia tem sua origem na Grécia Clássica a partir de duas perguntas básicas: o que ensinar? Como ensinar?

No âmbito ainda do Período Clássico, destaca-se a fase helenística, período da história da Grécia compreendido entre a morte de Alexandre III (O Grande) da Macedônia, em 323 a.C., e a anexação da península grega e ilhas por Roma, em 147 a.C. Devido à grande expansão e à dominação do Império grego a outras regiões, a educação desse período é chamada de helenística/enciclopédica e ficou conhecida como cultura Alexandrina (em homenagem ao Imperador Alexandre, o Grande, e suas várias

\footnotetext{
3 Professor de ginástica e jogos na Grécia; monitor; ginasta.
}

\begin{tabular}{|l|l|l|l|l|}
\hline Qonista Dialectus & Ano 3 & n. 9 & Setembro - Dezembro 2016 & p. 81 - 99 \\
\hline
\end{tabular}


conquistas). Essa fase é correspondente à expansão do Império grego com as conquistas e colonização da região da Campânia, Sicília e Itália.

Nesse período, há uma certa unificação da cultura greco-romana do ponto de vista eurocêntrico. A educação grega é alavancada em razão do desenvolvimento democrático nas cidades e da possibilidade do acesso à educação a todos os cidadãos gregos. Os fatores políticos, econômicos, sociais e culturais remetem o período helenístico à busca da educação nos moldes clássicos com três graus de ensino:

- O grau elementar, dos 7 aos 14 anos, foi pouco alterado relativamente à época clássica, mas conheceu uma extensão geográfica e social. - O grau equivalente ao ensino secundário após os 14 anos foi generalizado à época de Aristóteles (384322 a.C., fundador do Liceu em Atenas) e este ensino equilibrava formação literária e formação científica. Esta última compreende a geometria (os Elementos de Euclides), a aritmética (essencialmente o estudo do número inteiro), a astronomia geralmente ligada à astrologia, e a acústica. $\mathrm{O}$ estudo destas disciplinas é indiferente às aplicações práticas. $\mathrm{O}$ ensino das letras faz com que se conheçam os autores clássicos através de um método específico de exploração textual [...]. - O equivalente do ensino superior oferecia quatro vias ao estudante. A medicina com as escolas de Pérgamo, de Éfeso ou de Alexandria, a erudição com os museus (instituições que reúnem coleções de arte e de livros, criados na Alexandria, multiplicados nas monarquias helenísticas que a eles acrescentaram uma função de ensino), a retórica e a filosofia. Cada escola de filosofia - o Liceu (Aristóteles), o Pórtico (os estóicos), o Jardim (os epicuristas), a escola dos cínicos apresenta a sua solução para atingir a felicidade pela virtude. (Arenilla et al., 2001, p. 181).

Paulatinamente, o Império grego entra em decadência até, finalmente, ser conquistado pelo Império romano (146-147 a.C.). Em linhas gerais, no período helenístico, prevalece na educação a marca da Escola de Platão, fundador da Academia, representando a educação superior, da Escola de Aristóteles, idealizador do Liceu, representando a educação intermediária, e das Escolas Pirronista, Epicurista e Estoicista.

Além da Academia de Platão e do Liceu de Aristóteles, outras escolas foram sendo desenvolvidas no período helenístico: Estoicista, Epicurista e Pirronista. As escolas de Platão e Aristóteles tinham um papel essencial na definição e na 
interpretação das teorias de seus fundadores. Já o estoicismo, o epicurismo e o pirronismo possuíam um pensamento diverso dessas escolas, buscando uma visão diferenciada da ética e, portanto, da educação ou Paideia, pois se baseavam em repassar para seus discípulos fundamentos teóricos que pudessem estabelecer princípios que instruiriam uma vida moralmente correta e, essencialmente, uma vida feliz. Essas escolas divergem quanto a alguns aspectos teóricos que influenciam os princípios éticos que fundamentam cada concepção de educação. (Cabral, 2014, s.p.).

Sem dúvida, as diferentes concepções dessas escolas foram influenciadoras para os debates e a consolidação cada vez mais da filosofia, em particular, e da educação, em geral, na Paideia grega. Vale a pena ressaltar que as Escolas Pirronista, Estoicista e Epicurista divergiam em muitos aspectos teóricos das Escolas de Platão e Aristóteles. A Escola de Pirro negava por completo o legado platônico-aristotélico. O Pirronismo coloca:

[...] em dúvida todo o conhecimento humano, pois as coisas são, em si, impossíveis de se conhecer, ou seja, 'cada coisa não é mais que aquilo', e, assim, nossas representações estão anuladas e qualquer tentativa de formar juízos sobre qualquer sensação obtida está fadada ao fracasso. Desse modo, aqueles que desejam ser felizes devem manter a abstenção de juízo e ficar sempre indiferentes diante das coisas, pois as tentativas de formação de qualquer tipo de juízo estão impossibilitadas; logo, aqueles que insistem em tal ato somente conseguirão a perturbação da alma, o que é totalmente contrário ao ideal de felicidade, que é a apatia ou imperturbabilidade da alma. (Cabral, 2014, s.p.).

Procurar investigar para saber a essência das coisas seria o mesmo que procurar ser infeliz na concepção pirronista. Desse modo, se queres ser feliz, deixai as coisas como estão, em seus devidos lugares de origem, imutáveis. Essa é a melhor forma de viver em paz e com felicidade. Fechai os olhos diante das propostas de Platão, para quem o conhecimento seria uma aproximação máxima da identidade do objeto, e de Aristóteles, para quem o conhecimento seria um ato idêntico ao objeto.

Com relação ao Epicurismo, esta Escola não nega a possibilidade de se alcançar o conhecimento das coisas, já que tudo é composto por milhares de partículas atômicas formadoras de matéria exterior, fora do ser, sentidas por nossos órgãos sensoriais, podendo significar momentos de felicidade ou de dor.

\begin{tabular}{|l|l|l|l|l|}
\hline Qevista Dialactus & Ano 3 & n. 9 & Setembro - Dezembro 2016 & p. 81 - 99 \\
\hline
\end{tabular}


Dessa forma, nossa sensação é perfeitamente capaz de nos remeter ao mundo exterior e, sobretudo, de dar-nos certeza de encontrar a verdade (a coisa em si). É nesse contato com a verdade que os preceitos morais epicuristas encontram seus fundamentos: quando as coisas entram em contato com nossa sensação, despertam-nos um sentimento de prazer ou de dor, sendo que o critério para discernir o que é bom para o indivíduo é o prazer; e para discernir o que não é bom, a dor. Porém, não é todo o sentimento de prazer que promove a felicidade; desse modo, explica-se a existência de prazeres naturais e necessários, outros naturais, mas não necessários, e ainda não naturais e não necessários. Assim, Epicuro concede à sabedoria fundamental importância para o bem julgar, pois, estabelecidos os cânones (máximas) destinados a orientar seus discípulos a distinguirem de forma correta os prazeres e para que eles sempre escolham os prazeres naturais e necessários, proporciona a todos a saúde do corpo e a tranquilidade da alma e, em consequência disso, a felicidade [...]. Por fim, a educação epicurista almejaria, sobretudo, sob o alicerce da sabedoria, formar o indivíduo moral e orientar suas ações, mantendo sua alma longe dos temores do vulgo, das paixões e dos vícios (dor), enquanto procura prazeres naturais e necessários para estabelecer uma vida saudável, tranquila e, enfim, feliz. (Cabral, 2014, s.p.).

A Escola Epicurista tinha por finalidade educar o ser humano a procurar sempre viver de maneira regrada, tranquila, saudável, sem vícios, para poder chegar ao estado de felicidade. Baseada na fundamentação da moral como princípio fundamental para a formação do ser humano, a Escola Epicurista prima por uma educação em busca da saúde corpórea e paz de espírito. É possível ser feliz sem temer ou mendigar tal estado aos deuses e/ou ter medo da morte.

Com relação à Escola Estoica, esta acredita que a natureza do ser é o todo e o tudo em matéria de existência e o homem é por natureza um ser racional. Segundo o estoicismo, existe um princípio ontológico para que o ser humano possa viver feliz: aprender a conviver respeitosamente com sua própria natureza constituidora, afastando de si toda e qualquer intempérie negativa da formação e condução para o bem.

De acordo com os estoicos, ser feliz é, também, estar ou viver de acordo com a natureza; logo, devemos primeiramente observar a natureza do homem. Ele é um animal que necessita de conservação, isto é, que precisa alimentar-se e procriar-se [...]. Assim, para os estoicos, a educação se basearia no esclarecer ao indivíduo que, conscientizado e seguindo sua razão 
conjuntamente com todos os critérios de juízo, terá a perfeita condição de estar constantemente prudente ao estabelecer juízos para execrar tudo o que não aperfeiçoe sua natureza, mantendo longe de si toda e qualquer paixão, a fim de viver com felicidade. (Cabral, 2014, s.p.).

Essa é uma condição sine qua non para o desenvolvimento adequado da razão. Faz-se necessário viver de acordo com a natureza das coisas. É de suma importância que a educação tenha por objetivo formar uma consciência no homem para que ele seja capaz de evitar os maus julgamentos e as paixões. Para ser feliz, o ser necessita ser prudente em todas as suas ações e afastar de si o que lhe seja prejudicial de alguma forma.

Apesar de a educação grega, de um modo geral, ser caracterizada como educação liberal, não incluía as mulheres na educação formal. Daí as razões de a presente discussão sobre os diversos contextos e formas a respeito de como se deu a evolução da educação no mundo grego não ter falado sobre a educação feminina em momento algum. $\mathrm{O}$ fato é que as mulheres não eram incluídas nesse processo, pois a cultura grega as condicionava às atividades domésticas e ao zelo pela família. Jamais o sexo feminino poderia estar à frente das responsabilidades político-administrativas, inclusive na educação. Conforme resume Tsuruda (1994, p. 21): “[...] na civilização grega a mulher é um ser incapaz, que não pode desempenhar adequadamente as funções sem o apoio e supervisão do homem”.

\section{Educação em Roma: o legado greco-romano}

O processo educacional do período clássico grego deságua na sociedade romana, ficando conhecida como cultura greco-romana. Esse fato é decorrente da herança dos fundamentos educacionais aos moldes da Paideia grega, aplicados pelos romanos a partir de então.

Em Roma a educação moral, cívica e religiosa, aquela que chamamos de inculturação às tradições pátrias, tem uma história com características próprias, ao passo que a instrução escolar no sentido técnico, especialmente das letras, é quase totalmente grega [...]. O que é incontestável é que, ao confrontarmos a história da educação romana com a grega, na Roma antiga procuraremos em vão algum educador estrangeiro ou banido de sua pátria, como o Fênix ou o Pátroclo de Homero, mas veremos 
emergir em primeiro plano a função educador do pai. (Manacorda, 2006, p. 73).

A educação na sociedade romana em diante fundamentou-se através do pater-família, ou seja, o pai, que desempenhava a função de Senhor e Sacerdote da família, era o principal responsável pela educação das crianças. Esta parece ser uma realidade geral nas sociedades patriarcalistas. Verifica-se a importância de se conhecer ao menos certas características gerais do legado da educação romana. Nas palavras do sociólogo Émile Durkheim (1995, p. 25): "Toda a matéria-prima de nossa civilização intelectual nos veio de Roma. É possível prever, portanto, que nossa pedagogia, os princípios fundamentais de nosso ensino vieram até nós da mesma fonte [...]".

A educação romana, no âmbito das famílias abastadas, passou a funcionar por meio de professores contratados com hospedagem nas próprias residências dos alunos. Normalmente o contratado era um docente grego, pedagogo ou escritor literata. Por outro lado, para os filhos das famílias de menor poder aquisitivo, existiam as escolas de caráter privado, com dois graus de ensino-aprendizagem: a escola de Literatura e a de Gramática. A primeira ensinava sobre as obras de literatura, suas interpretações e produções; e a segunda ensinava a língua grega e latina para que os discentes aprendessem a cultura grega. Esse ensino era de caráter geral e intermediário. Em caráter de nível superior, existiam as escolas de retórica, com a finalidade do bem escrever, da retórica e do ingresso na vida política. Na educação romana, alguns docentes se destacaram, tais como: Lucio Eneu Sêneca (4 a.C. -65); Marco Fabío Quintilíano (35-95); Marco Túlio (106-43); Marco Pórcio Catão (234-149) (Manacorda, 2006).

Todavia, diversas especificidades ou diferenciações da educação romana em relação à educação grega merecem ser destacadas. A característica geral e acentuada da educação romana era o pragmatismo, ou seja, uma educação voltada para o modelo prático-social e o método imitativo foi seu principal fundamento. Enquanto os gregos primaram por uma educação liberal, sobretudo a partir do período clássico, e tinham seus heróis como semideuses, já “[...] os heróis romanos, ao contrário, podiam ser imitados por todo menino romano [...]. O jovem romano tinha de tornar-se piedoso, respeitoso, corajoso, varonil, prudente, honesto pela imitação de seu pai e de outros romanos", considerados heróis de seu país (Piletti et al., 2007, p. 75). 
Outras atividades educativas praticadas pelos gregos também não eram aceitas pela educação romana, como: ginástica, dança, música, etc. Essas atividades eram consideradas como atividades estimuladoras à afeminação pelos romanos. Além disso, no plano pedagógico, a educação romana anexou:

- um material didático com o mapa de geografia e o quadro mural sem dúvida exigido pelos efectivos distintos; - a viagem à Grécia para seguir os estudos superiores; - o bilinguismo. O latim impõe-se como língua nacional na administração e no exército, mas o sistema educativo, pelo menos até o século III da nossa era, escolhe a língua grega como instrumento de cultura; [...]. A adoção em Roma da organização e dos métodos de educação helenísticas faz-se acompanhar por uma inflexão da cultura num sentido utilitário. Este manifesta-se na recusa da educação grega do corpo, vista como aperfeiçoamento e estético e prazer gratuito. (Arenilla et al., 2001, p. 184).

Entretanto, nem sempre de áurea a cultura grega está presente em Roma. Com efeito, a cultura helenística tem seu menosprezo simbolizado nas três principais expressões ou espaços culturais de desenvolvimento estético corporal: o ginásio, a palestra e o estádio. O ginásio grego é substituído pelo jardim de diversão; a palestra, pelas termas; e o estádio-anfiteatro, pelo circo.

A decadência da educação romana, dentre outras causas, deveu-se ao tipo de educação elitista e ao desprezo intelectual da grande massa constituidora do grande Império Romano, que levou a outros problemas enfraquecedores e corrosivos daquela sociedade. Paul Monroe (1983, p. 91 apud Piletti et al., 2007, p. 78) resume a decadência da educação e outros males que consequentemente causaram a ruição do Império romano no Ocidente, em 476 d.C., nas mãos do germânico Odoacro, rei dos hérulos:

A educação já não se destina a ser a educação prática do povo, mas o ornamento de uma sociedade oca, superficial e geralmente corrupta; já não é um estádio de desenvolvimento possível para um povo inteiro, ou para indivíduos de dada categoria, mas a simples obtenção ou mesmo mera insígnia de distinção de uma classe favorecida. Quando o antigo vigor político e as oportunidades para as atividades políticas desapareceram, quando o governo municipal se tornou mera máquina para coletar impostos, quando o exército se encheu de bárbaros, a classe superior, agora mais numerosa do que nunca,

\begin{tabular}{|l|l|l|l|l|}
\hline Qenista Qialectus & Ano 3 & n. 9 & Setembro - Dezembro 2016 & p. 81 - 99 \\
\hline
\end{tabular} 
voltou-se para o único traço remanescente da Primitiva Roma imperial - sua cultura.

Lembrando que a queda do Império romano do Ocidente se deu devido às invasões germânicas, pois as migrações desses povos para o território há muito vinham sendo aceitas tacitamente, ou pela compra de territórios a governantes romanos corruptos, ou pela cooptação de um exército mercenário e não remunerado dignamente pela governança do Império romano. Com o imenso Império romano, vão-se as estruturas e a importância social da educação elitista, juntamente com a governabilidade imperial e o modo de produção vigente.

\section{Referências:}

ABBAGNANO, N. Dicionário de filosofia. São Paulo: Martins Fontes, 1998.

ARENILLA, L. et al. (Org.). Dicionário de pedagogia. Lisboa: Piaget, 2001.

AZEVEDO, G. C. et al. História: volume único. São Paulo: Ática, 2005.

BERGSON, H. A evolução criadora. Lisboa: 70, 1941.

CABRAL, João Francisco Pereira. "A educação no período Helenístico: a Paideia na época de Alexandre, o Grande" In: Brasil Escola. Disponível em $<$ http://brasilescola.uol.com.br/filosofia/a-educacao-no-periodo-helenistico-paideia-naepoca-alexandre.htm>. Acesso em: 20 out. 2016.

DURKHEIM, E. A evolução pedagógica. Porto Alegre: Artes Médicas, 1995.

FOUCAULT, M. Vigiar e punir: nascimento da prisão. 39. ed. Petrópolis: Vozes, 2011.

FREIRE, P. Ação cultural para a liberdade. São Paulo: Paz e Terra, 1976.

GADOTTI, M. A questão da educação formal/não formal. Sion Institut International dês Drois de I'Enfant, 2005.

GOHN, M. G. Educação não formal, participação da sociedade civil e estruturas colegiadas nas escolas. Ensaio: avaliação e políticas públicas em educação, Rio de Janeiro, v. 14, n. 50, p. 27-38, 2006.

MANACORDA, M. A. História da educação. Da Antiguidade aos nossos dias. 12. ed. São Paulo: Cortez, 2006.

MARX, K. et al. A ideologia alemã. Lisboa: Presença, 1976.

\begin{tabular}{|l|l|l|l|l|}
\hline Qevista Dialactus & Ano 3 & n. 9 & Setembro - Dezembro 2016 & p. 81 - 99 \\
\hline
\end{tabular}


MEKSENAS, P. Sociologia da educação: introdução ao estudo da escola no processo de transformação social. São Paulo: Loyola, 1988.

MONROE, P. História da educação. São Paulo: Nacional, 1979. In: PILETTI, C. et al. Filosofia e história da educação. 5. ed. São Paulo: Ática, 2007.

PILETTI, C. et al. Filosofia e história da educação. 5. ed. São Paulo: Ática, 2007.

RIBEIRO, L. T. F. et al. In: VASCONCELOS JÚNIOR, R. E. P. et al. (Org.). Cultura, educação, espaço e tempo. Fortaleza: 2011.

TSURUDA, M. A. L. Os modelos de educação feminina em Homero. Cadernos de História e Filosofia da Educação, São Paulo, v. 1, n. 3, 1994. 